\title{
EVALUATION OF THE ROCKS OF THE PILA SPI FORMATION OF DUHOK ANTICLINE FOR BUILDING STONES - KURDISTAN REGION OF IRAQ
}

\author{
Ameer Hayder Khalid \\ Department of Geology, College of Science, University of Duhok, Kurdistan Region, Iraq - (ameer.khalid@uod.ac)
}

Received: Aug., 2021 / Accepted: Dec., 2021 / Published: Dec., 2021

https://doi.org/10.25271/sjuoz.2021.9.4.837

\begin{abstract}
:
The rocks of the Pila Spi Formation at the southern limb of the Duhok anticline have been evaluated for use as building stones. The geology of the area and examined rocks are described. Nine samples were collected and tested for physico-mechanical properties (total porosity, water absorption, saturation coefficient, apparent specific gravity, bulk density and uniaxial compressive strength). There was a remarkable variation between the samples in these properties, which showed very high significant relationships with each other. Samples were classified as frostresistant. According to the Iraqi and American Standards, four samples were categorized as (low density/acceptable), three samples as (moderate density/recommended) and two samples as (high density/highly recommended). According to some classifications, the samples were (moderately strong) except for two of them were (strong), while all of them were (moderately strong) and (high strength rocks) in other classifications. The examined rocks are suitable for interior and exterior wall cladding and exterior fencing, as well as for decoration. Four of them are not suitable for building sections that require high load bearing or in places where they come into contact with water or soil, such as foundations, while only two samples are suitable. The quality and quantity of the rocks and the quarrying conditions encourage their exploitation for building stones, with the necessity of proper planning of the proposed quarry and special treatment during quarrying.
\end{abstract}

KEYWORDS: Building Stones, Duhok Anticline, Kurdistan Region, Physico-mechanical Properties, Pila Spi Formation, Quarrying.

\section{INTRODUCTION}

Natural building stones are rocks of sedimentary, igneous or metamorphic origin that are sufficiently hard to be cut into slabs or blocks to be utilized as paving, walling or roofing materials in the construction of modern structures and buildings. Field studies and laboratory examinations are irreplaceable to evaluate the stone quality for construction uses (Saffet, 2010). Building stones must be of high quality for their physical, mechanical and dynamic properties which play a pivotal role in designing civilian construction works (Sharma et al., 2006; Bhattarai and Tamrakar, 2017).

Building stones utilized in the interior and exterior designs of buildings are among the most globally common construction materials. They are found extensively in the geological column and have a wide distribution. Their use is restricted when structural complexities or overburden make their production unprofitable or when conservation of nationally or internationally designated heritage sites prevents active quarrying (British Geological Survey, 2005). Building stones exhibit an awfully wide textural and mineralogical composition depending on their origin.

Examination of the physical and mechanical properties of rocks is imperative in deciding their engineering behavior and assessing their use in the numerous sections of the building (Ali et al., 1991; Griffin, 2008). These properties depend primarily on the type and hardness of the mineral constituents, grain size, porosity and pore size, nature of occurrence, degree of weathering, alteration and, in some cases, presence of microfractures (Abd El-Hamid et al., 2015). Rocks are classified according to their properties to obtain valuable information in preparing engineering designs for the project to be built.

The Pila Spi Formation (Middle - Late Eocene) covers broad areas and forms prominent ridges between the Gercus and Fatha Formations in the Kurdistan Region of Iraq. Numerous researchers have discussed its suitability for building stones and industrial usages. The present work aims to evaluate the rocks of this formation in the Duhok anticline for building stones based on the laboratory examination of their physico-mechanical properties and some basic quarrying conditions and considerations.

\section{PREVIOUS WORKS}

Quarries that exploit the rocks of the Pila Spi Formation for various construction and industrial utilizes are located in many areas of the Kurdistan Region of Iraq and other neighboring provinces. The following is a summary of the studies that evaluated these rocks for building and other construction purposes:

Dhaher (2009) concluded that the rocks of the Pila Spi Formation in Shaqlawa area were strong and durable enough to be used as building stones. Saleh (2012) explained that limestone rocks in the Pila Spi Formation in the Nineveh Governorate can be utilized as exterior walls covering, decoration, and as construction aggregate. Khattab and Othman (2012) deduced from their study of the durability and strength of limestone rocks of the Pila Spi Formation from three quarries in the Nineveh and Duhok Governorates that the strength values for these rocks differ between and within the same quarry. They classified the rocks as (medium - strong), (weak medium) and (weak). The rocks can be used as the main material for the skeleton of buildings or for external cladding purposes. Some types of these rocks can be used in areas that are not exposed to the influence of water or moisture, and one type is not suitable for use as a construction material. Al-Banna et al. (2013) reported that the geotechnical characteristics of the Pila Spi and Injana Formations from two limbs of a syncline located in the Shaqlawa area vary depending on plentiful key factors such as water saturation, the relative location of the specimen within the syncline limbs and lithology. Each limb of the syncline has different geotechnical characteristics due to the nature and degree of stresses affecting each limb. Omar and Ismail (2015) evaluated limestone from the Pila Spi Formation in Koya area for use as a building stone and concluded that it has low porosity, high density and is hard enough for use in foundations, wall cladding and building coverings. Mirza and Rashid (2019) assessed the Pila Spi Formation in Qara Dagh area and concluded that the carbonate rocks of this formation can be used as a dimension stone. 


\section{GEOLOGIC SETTING}

The studied area is situated tectonically within the High Folded Zone of the Zagros Foreland Basin according to Fouad (2015), and within the High Folded Zone of the Unstable Shelf according to Jassim and Goff (2006). The investigated rocks are exposed in a sequence at the southern limb of the Duhok anticline (Zawa Mountain), approximately $1 \mathrm{~km}$ west of the Sinaye Old village, and $4.25 \mathrm{~km}$ northeast of the Sharya District, which is about $11 \mathrm{~km}$ south of Duhok city (Figs.1 and 2).

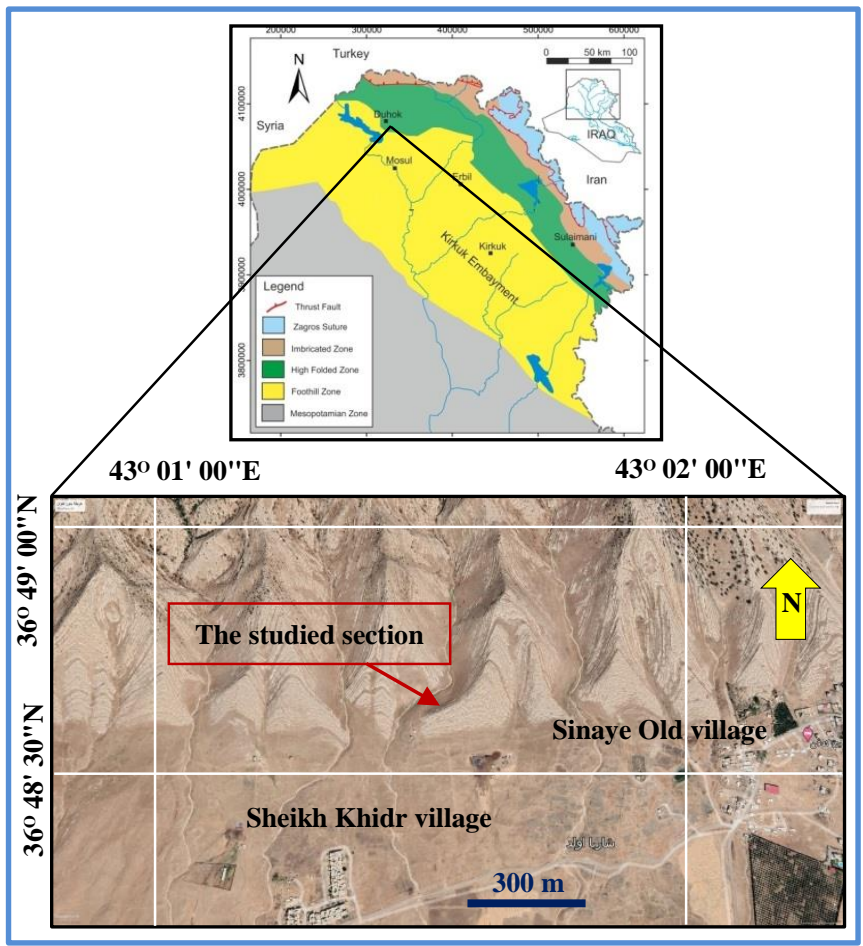

Figure 1. Google Earth image showing the location of the studied section at the southern limb of the Duhok anticline.

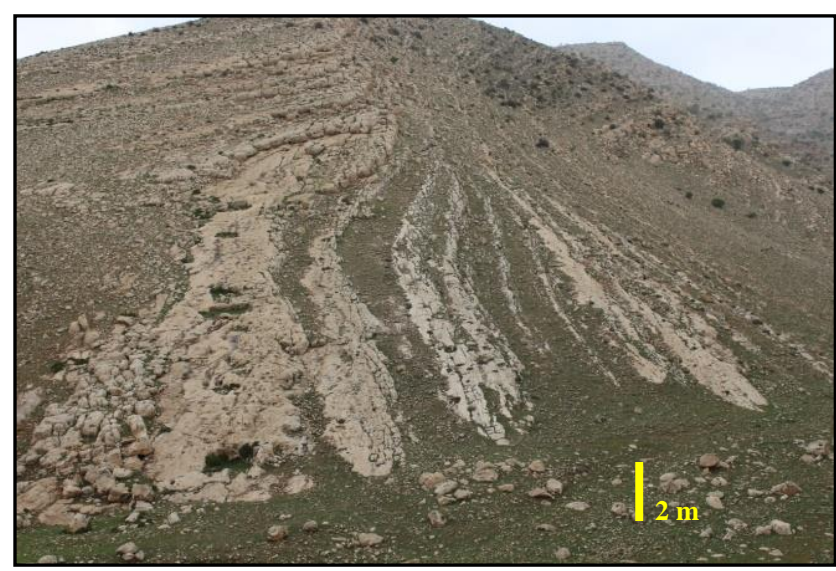

Figure 2. The Pila Spi Formation layers within the studied section.

The Duhok anticline is an asymmetrical fold, extending $\mathrm{E}-\mathrm{W}$, nearly $20 \mathrm{~km}$ long and $3-5 \mathrm{~km}$ wide and follows the Taurus folding style (Alkadum, 2009). The dip angle of the northern limb varies between $40^{\circ}-79^{\circ}$, and between $14^{\circ}-44^{\circ}$ at the southern limb (AlKadum, 2009). The anticline has very well exposures of the Pila Spi Formation which forms high anticlinal ridges. The anticline is neighbored on the north by the Bekhair anticline and is separated by a very narrow syncline owing to the high dip of the southern limb of the Bekhair anticline and the northern limb of the Duhok anticline.
It is neighbored to the south by the Dahkan anticline, to the east by the Brifka anticline, and to the west by the Sumail anticline (Sissakian et al., 1995; AlKadum, 2009; Al-Saraj Bashi, 2017) (Fig.3).

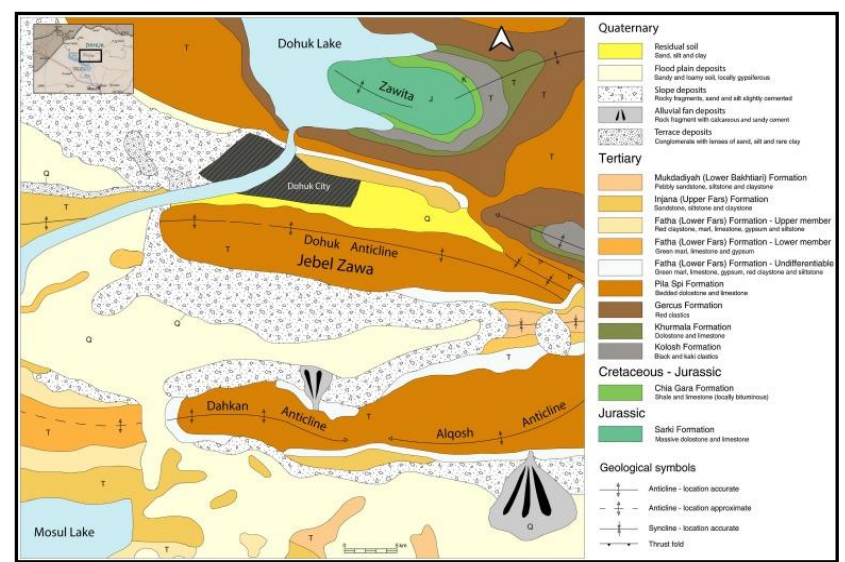

Figure 3. Geological map of the Duhok area. (After Sissakian et al., 1995).

The exposed layers include joints of (hko) system overwhelmingly, and (hol) and (okl) to a lesser extent. These joints are filled with carbonate materials due to the processes of weathering and erosion. The main geomorphological units of the area with structural and structural-denudational origins are plateau, anticlinal ridges, transverse valleys, cuestas, karst cavities and flatirons (Fig.4). Landforms resulting from mass movement, such as rock fall, rock toppling and debris flow are also found in the area (Fig.5).

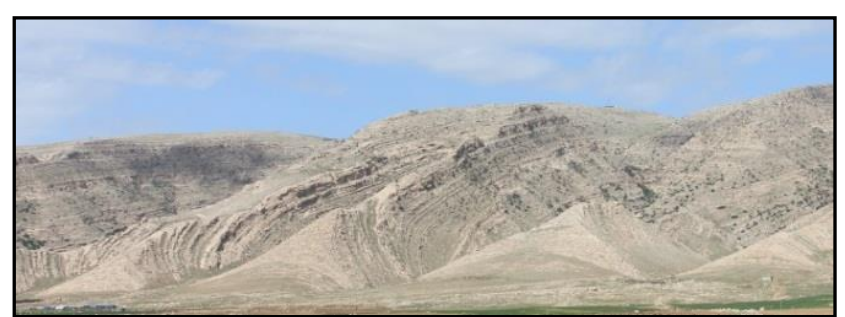

Figure 4. Flatirons within the Pila Spi Formation at the southern limb of the Duhok anticline.

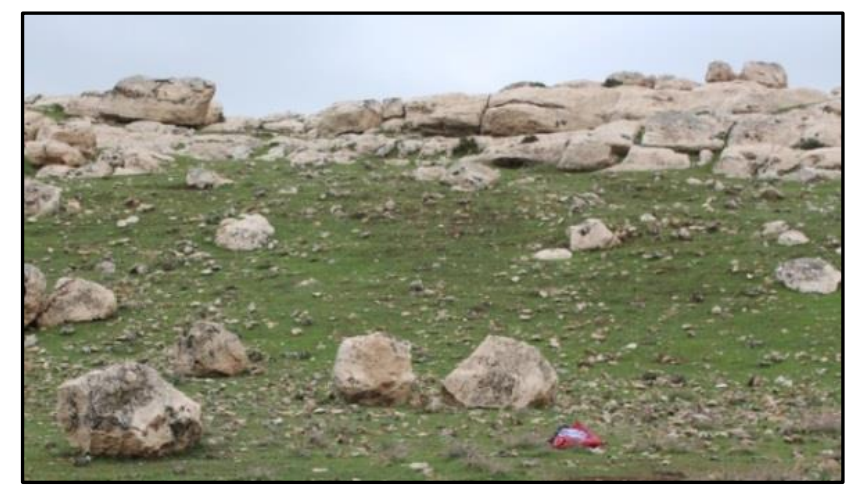

Figure 5. The phenomenon of rock falls in the studied area.

The thickness of the Pila Spi Formation in the studied area is about $150-200 \mathrm{~m}$ and consists, from top to downward, of a sequence of consolidated, crystallized limestone, well-bedded to massive white or gray dolomitic limestone that is occasionally chalky and cavernous with scattered nodules of chert of different sizes and shapes in some intervals (Fig.6). Small signs of oxidation occur on the surface of the rocks. The thickness of the layers varies between $0.5-2 \mathrm{~m}$. Nodules of chert are present in horizons with a maximum thickness of $20 \mathrm{~m}$ towards the core of the anticline (Barbaro and Moscone, 2020; Moscone et al., 2020). Locally, the formation is 
overlain by one or more of the Oligocene rocks of the Kirkuk Group and Quaternary deposits (AlKadum, 2009; Karim and Hama, 2019).

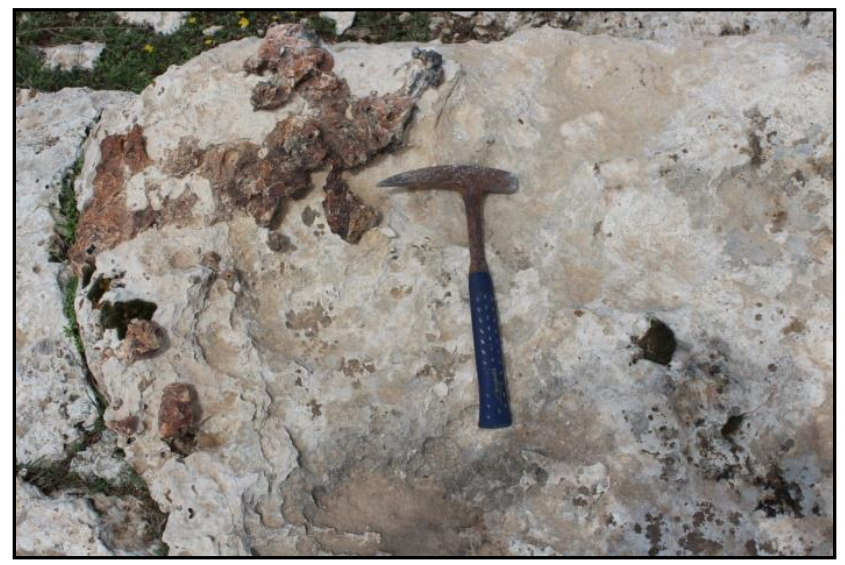

Figure 6. Nodules of chert in the dolomitic limestones.

\section{MATERIALS AND METHODS}

\subsection{Sample Preparation and Testing}

In this study, nine large, fracture - and void - free samples were collected from a section within the Pila Spi Formation at the southern limb of the Duhok anticline. The rock sampling began from the bottom of the section at coordinates $36^{\circ} 48^{\prime} 40^{\prime \prime} \mathrm{N}$ and $43^{\circ} 01^{\prime}$ $27^{\prime \prime E}$, elevation of $606 \mathrm{~m}$ (a.s.1.) and ended at the top of the section at coordinates $36^{\circ} 48^{\prime} 41^{\prime \prime} \mathrm{N}$ and $43^{\circ} 01^{\prime} 36^{\prime \prime} \mathrm{E}$, elevation of $649 \mathrm{~m}$ (a.s.1.). The thickness of the sampled section is $43 \mathrm{~m}$. The sampling interval ranged from 3 to $5 \mathrm{~m}$. Table (1) shows the field description of the collected samples.

Table 1. Field description of the collected samples.

\begin{tabular}{|c|c|c|c|}
\hline $\begin{array}{c}\text { Sample } \\
\text { No. }\end{array}$ & $\begin{array}{c}\text { Bed } \\
\text { Thickness } \\
\text { (m) }\end{array}$ & $\begin{array}{c}\text { Sampling } \\
\text { interval } \\
(\mathbf{m})\end{array}$ & Description \\
\hline S1 & 0.90 & 5 & $\begin{array}{c}\text { White, well-bedded, chalky } \\
\text { limestone }\end{array}$ \\
\hline S2 & 1.10 & 5 & $\begin{array}{c}\text { White to light gray, } \\
\text { massive, hard dolostone }\end{array}$ \\
\hline S3 & 1.25 & 5 & $\begin{array}{c}\text { Light gray, massive, hard } \\
\text { calcareous dolostone }\end{array}$ \\
\hline S4 & 1.20 & 5 & $\begin{array}{c}\text { Light gray, massive } \\
\text { dolostone }\end{array}$ \\
\hline S5 & 1.0 & 5 & $\begin{array}{c}\text { Light gray and cherty } \\
\text { dolostone }\end{array}$ \\
\hline S6 & 1.15 & 3 & $\begin{array}{c}\text { Light brown, jointed } \\
\text { calcareous dolostone }\end{array}$ \\
\hline S7 & 1.30 & 3 & $\begin{array}{c}\text { White, thickly bedded } \\
\text { chalky limestone }\end{array}$ \\
\hline S8 & 1.20 & 5 & $\begin{array}{c}\text { White, thickly bedded } \\
\text { chalky limestone }\end{array}$ \\
\hline S9 & 0.90 & 5 & $\begin{array}{c}\text { White, well-bedded, jointed } \\
\text { chalky limestone }\end{array}$ \\
\hline
\end{tabular}

The samples were examined for physico-mechanical properties in the Duhok Construction Laboratory in Sumail using the Iraqi Standard No.1387, 1989 and ASTM C97-09-2010. The sample preparation and testing procedures are as follows:

- A portion of each sample weighing about $250-300 \mathrm{~g}$ was broken into small pieces of $12.5-25 \mathrm{~mm}$ in size and their normal weight $\left(\mathrm{W}_{\mathrm{N}}\right)$ was recorded.

- The pieces were dried at $110{ }^{\circ} \mathrm{C}$ for 48 hours, placed in a desiccator for 30 minutes to cool to room temperature and their oven-dry weight $\left(\mathrm{W}_{\mathrm{D}}\right)$ was recorded.
- The pieces were soaked for 48 hours in a basin of distilled water connected to a desiccator, surface wiped with a damp cloth and their saturated weight $\left(\mathrm{W}_{\mathrm{W}}\right)$ was recorded.

- Finally, the pieces were suspended freely in a wire basket immersed in a distilled water container connected to a $0.01 \mathrm{~g}$ precision electronic scale and their submerged weight ( $\left.\mathrm{W}_{\mathrm{S}}\right)$ was recorded.

The samples were examined for uniaxial compressive strength using the Iraqi Standard No.2715, 1987. From each sample, three regular cubic-shaped specimens of $(100 \times 100 \times 100 \mathrm{~mm})$ were prepared and polished to obtain a smooth surface for uniaxial loading. The specimens in their natural state were placed perpendicular to the bedding plane in a compression testing machine at a constant rate of loading of $0.6 \mathrm{MPa} / \mathrm{mm}^{2} / \mathrm{sec}$. fixed by the compression machine and compressed until failure. The three breaking point values were averaged for each sample.

\subsection{Measurement of Physico-mechanical Properties}

The following properties were determined for the samples:

\subsubsection{Water Absorption (Aw) (\%):}

It is the capability of a rock submerged in water for 48 hours to absorb water (McMillan et al., 1999; Zeb, 2009). It is calculated as follows:

$\mathrm{Aw}_{\mathrm{W}}(\%)=\left(\mathrm{W}_{\mathrm{W}}-\mathrm{W}_{\mathrm{D}} / \mathrm{W}_{\mathrm{D}}\right) \times 100$

Where $\quad \mathrm{W}_{\mathrm{W}}=$ saturated weight $(\mathrm{g})$

$\mathrm{W}_{\mathrm{D}}=$ oven-dry weight $(\mathrm{g})$

The obtained value gives a sign of the service behavior of the stone, in particular its durability, strength, aesthetics, and stain resistance (Spry, 1989; Sandrolini and Franzoni, 2006).

\subsubsection{Total Porosity $(\phi)(\%)$ :}

It is the ratio of the volume of pores to the total volume of the rock, including solid components and pores (Honeyborne, 1982). It is calculated as follows:

$\phi(\%)=\left(\mathrm{W}_{\mathrm{W}}-\mathrm{W}_{\mathrm{D}} / \mathrm{V}_{\mathrm{t}}\right) \times 100$

Where $V_{t}=$ total volume of the rock $\left(\mathrm{cm}^{3}\right)$

\subsubsection{Saturation Coefficient $\left(S_{c}\right)$ :}

It is a measure of the degree to which rock pores are filled with absorbed water under certain conditions (McMillan et al., 1999). It is a unitless quantity and is calculated as follows:

$$
\begin{aligned}
& \mathrm{S}_{\mathrm{c}}=\mathrm{Aw}(\%) / \phi(\%) \\
& \mathrm{S}_{\mathrm{c}}=\left(\mathrm{W}_{\mathrm{W}}-\mathrm{W}_{\mathrm{S}}\right) / \mathrm{W}_{\mathrm{D}}
\end{aligned}
$$

Where $\quad \mathrm{W}_{\mathrm{S}}=$ submerged weight $(\mathrm{g})$

\subsubsection{Apparent Specific Gravity (G):}

It is the ratio of the weight in air per unit volume of the impermeable portion of the rock (not comprising the permeable pores) to the weight in air of an equal volume of gas-free distilled water at the specified temperature. It is calculated as follows (ASTM C97-092010):

$\mathrm{G}=\mathrm{W}_{\mathrm{D}} /\left(\mathrm{W}_{\mathrm{W}}-\mathrm{W}_{\mathrm{S}}\right)$

\subsubsection{Bulk Density $\left(\rho_{b}\right)$ :}

It is the mass of a unit volume of the rock. It is expressed by the mass of rock particles divided by the total volume they occupy which includes the particles, interparticle and intraparticle pores. 
Bulk density is calculated as follows (ASTM C97-09-2010):

$\rho_{\mathrm{b}}\left(\mathrm{g} / \mathrm{cm}^{3}\right)=\mathrm{W}_{\mathrm{N}} / \mathrm{V}_{\mathrm{t}}$

$\mathrm{V}_{\mathrm{t}}=\left(\mathrm{W}_{\mathrm{W}}-\mathrm{W}_{\mathrm{S}}\right) / \gamma_{\mathrm{W}}$

Where $\quad \mathrm{W}_{\mathrm{N}}=$ natural weight $(\mathrm{g})$

$\gamma_{\mathrm{W}}=$ density of water $\left(\mathrm{g} / \mathrm{cm}^{3}\right)$

4.2.6 Uniaxial Compressive Strength (UCS) ( $\sigma c)$ :

It is the stone's resistance to the vertical compression applied to it at the failure point. It is a measurement of the load that a stone can withstand until it breaks, and therefore it is a measurement of a stone's ability to back load-bearing components of a building (Taylor and Harold, 1991; Quick, 2002).

The uniaxial compressive strength is calculated according to the Iraqi Standard No.2715, 1987 and ASTM C170-90-1999 as follows:

$$
\sigma \mathrm{c}=\mathrm{P} / \mathrm{A}
$$

$$
\begin{aligned}
& \text { Where } \sigma c=\text { Compressive strength }\left(\mathrm{N} / \mathrm{mm}^{2}\right) \\
& \mathrm{P}=\text { Maximum failure load }(\mathrm{N}) \\
& \mathrm{A}=\text { Section area of the cubic specimen }\left(\mathrm{mm}^{2}\right)
\end{aligned}
$$

\section{RESULTS AND DISCUSSION}

\subsection{Laboratory Test Results:}

Table (2) summarizes the results of the physico-mechanical properties tests of the nine collected samples.

Table 2: Results of the physico-mechanical properties tests of the samples.

\begin{tabular}{|c|c|c|c|c|c|c|}
\hline Sample No. & $\mathbf{A}_{\mathbf{W}}(\boldsymbol{\%})$ & $\boldsymbol{\phi}(\boldsymbol{\%})$ & $\mathbf{S}_{\mathbf{c}}$ & $\mathbf{G}$ & $\mathbf{\rho}_{\mathbf{b}}\left(\mathbf{k g} / \mathbf{m}^{\mathbf{3}}\right)$ & $\boldsymbol{\sigma c} \mathbf{( M P a )}$ \\
\hline S1 & 9.61 & 19.29 & 0.50 & 2.0 & 2036 & 27 \\
\hline S2 & 2.74 & 6.90 & 0.40 & 2.52 & 2517 & 55 \\
\hline S3 & 2.81 & 7.14 & 0.39 & 2.54 & 2554 & 55 \\
\hline S4 & 5.07 & 11.90 & 0.43 & 2.35 & 2357 & 39 \\
\hline S5 & 3.33 & 8.20 & 0.41 & 2.46 & 2467 & 50 \\
\hline S6 & 4.11 & 9.84 & 0.42 & 2.39 & 2410 & 42 \\
\hline S7 & 9.13 & 19.55 & 0.47 & 2.14 & 2146 & 27 \\
\hline S8 & 7.84 & 16.58 & 0.47 & 2.12 & 2179 & 32 \\
\hline S9 & 7.40 & 15.24 & 0.49 & 2.06 & 2063 & 35 \\
\hline Mean & 5.78 & 12.74 & 0.44 & 2.29 & 2303.22 & 40.22 \\
\hline $\begin{array}{c}\text { Standard } \\
\text { Deviation }\end{array}$ & 2.74 & 5.07 & 0.04 & 0.20 & 199.68 & 11.08 \\
\hline
\end{tabular}

The samples showed a remarkable variation in the values of their physico-mechanical properties, which can be attributed to the differences in their lithology, depositional texture characteristics, and the degree of their influence by diagenetic and weathering processes. Samples (S1, S7, S8, and S9) have high values of water absorption coefficient and total porosity, and low values of apparent specific gravity, bulk density and uniaxial compressive strength compared to other samples. They are, therefore, more susceptible to increased and decreased humidity, less durable and resistant to weather conditions, and degrade faster.

Samples (S4, S5, and S6) have comparatively lower values of water absorption coefficient and total porosity, and higher values of apparent specific gravity, bulk density and uniaxial compressive strength, while samples (S2 and S3) have low values of water absorption coefficient and total porosity, and high values of apparent specific gravity, bulk density and uniaxial compressive strength. They are, therefore, less susceptible to increased and decreased humidity, more durable and resistant to climatic conditions.

The saturation coefficient of the examined samples varies due to the difference in their total porosity, which in turn varies depending on the lithology and the characteristics of the rock texture. The higher the porosity of the rock, particularly the percentage of narrow and connected voids in it, the faster the water rises through it. Therefore, samples are classified as frost-resistant according to (Honeyborne, 1982).

The statistical analysis revealed that the relationships between the examined properties of the samples are significant and very high. Table (3) shows the matrix of correlation coefficient $(r)$ values for the tested properties. Figures (7, 8, 9 and 10) show the diagrammatic representations of these relationships.

Table 3. Matrix of correlation coefficient ( $r$ ) values for the tested properties.

\begin{tabular}{|c|c|c|c|c|c|c|}
\hline Variable & $\mathrm{A}_{\mathrm{W}}$ & $\phi$ & $\mathrm{S}_{\mathrm{c}}$ & $\mathrm{G}$ & $\rho_{\mathrm{b}}$ & $\sigma \mathrm{c}$ \\
\hline $\mathrm{A}_{\mathrm{W}}$ & 1 & & & & & \\
\hline$\phi$ & 0.997 & 1 & & & & \\
\hline $\mathrm{Sc}$ & 0.957 & 0.938 & 1 & & & \\
\hline $\mathrm{G}$ & -0.965 & -0.949 & -0.998 & 1 & & \\
\hline$\rho_{\mathrm{b}}$ & -0.961 & -0.945 & -0.998 & 0.966 & 1 & \\
\hline$\sigma \mathrm{c}$ & -0.968 & -0.977 & -0.924 & 0.937 & 0.931 & 1 \\
\hline
\end{tabular}



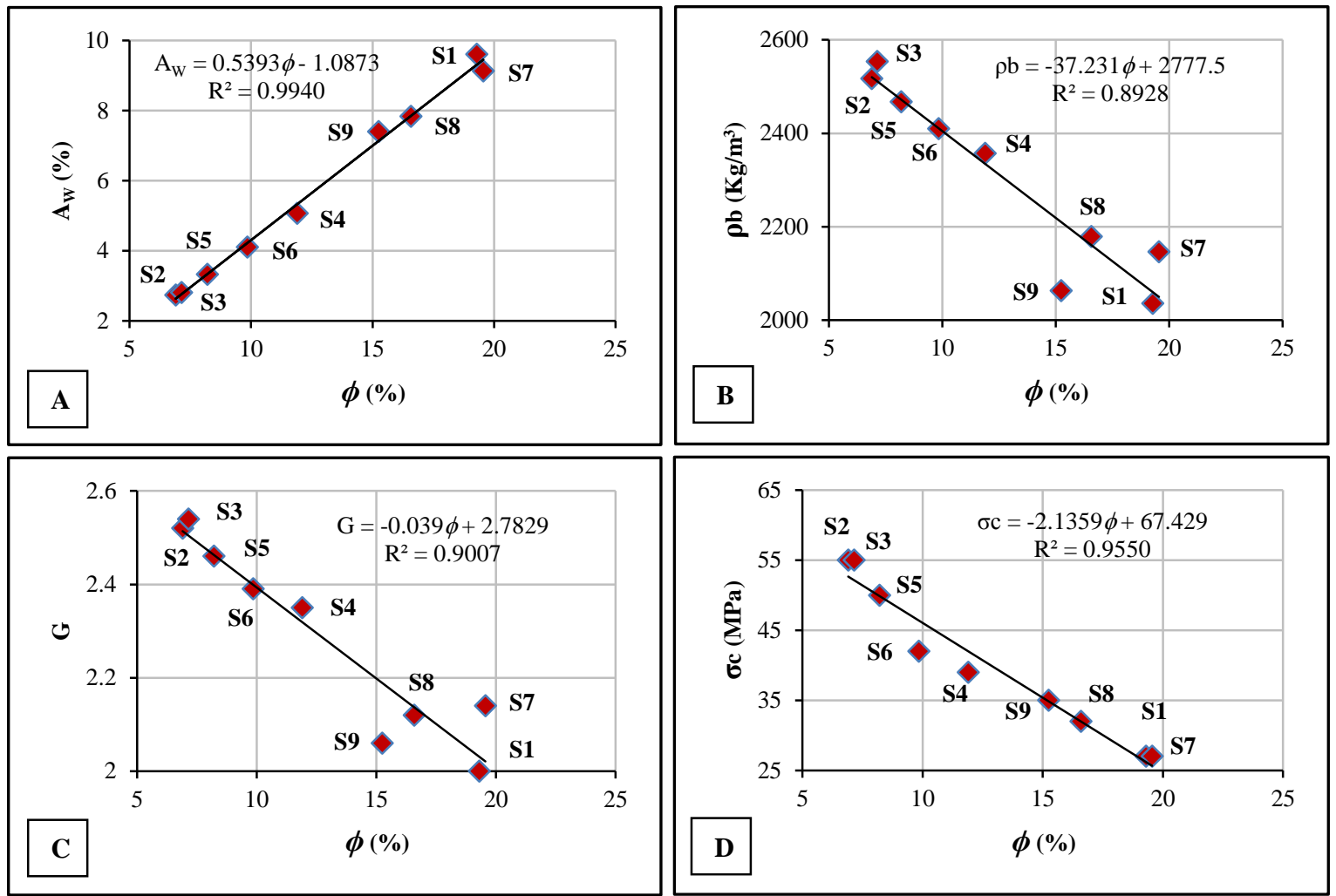

Figure 7. The total porosity versus A) water absorption, B) bulk density, C) apparent specific gravity, D) uniaxial compressive strength.
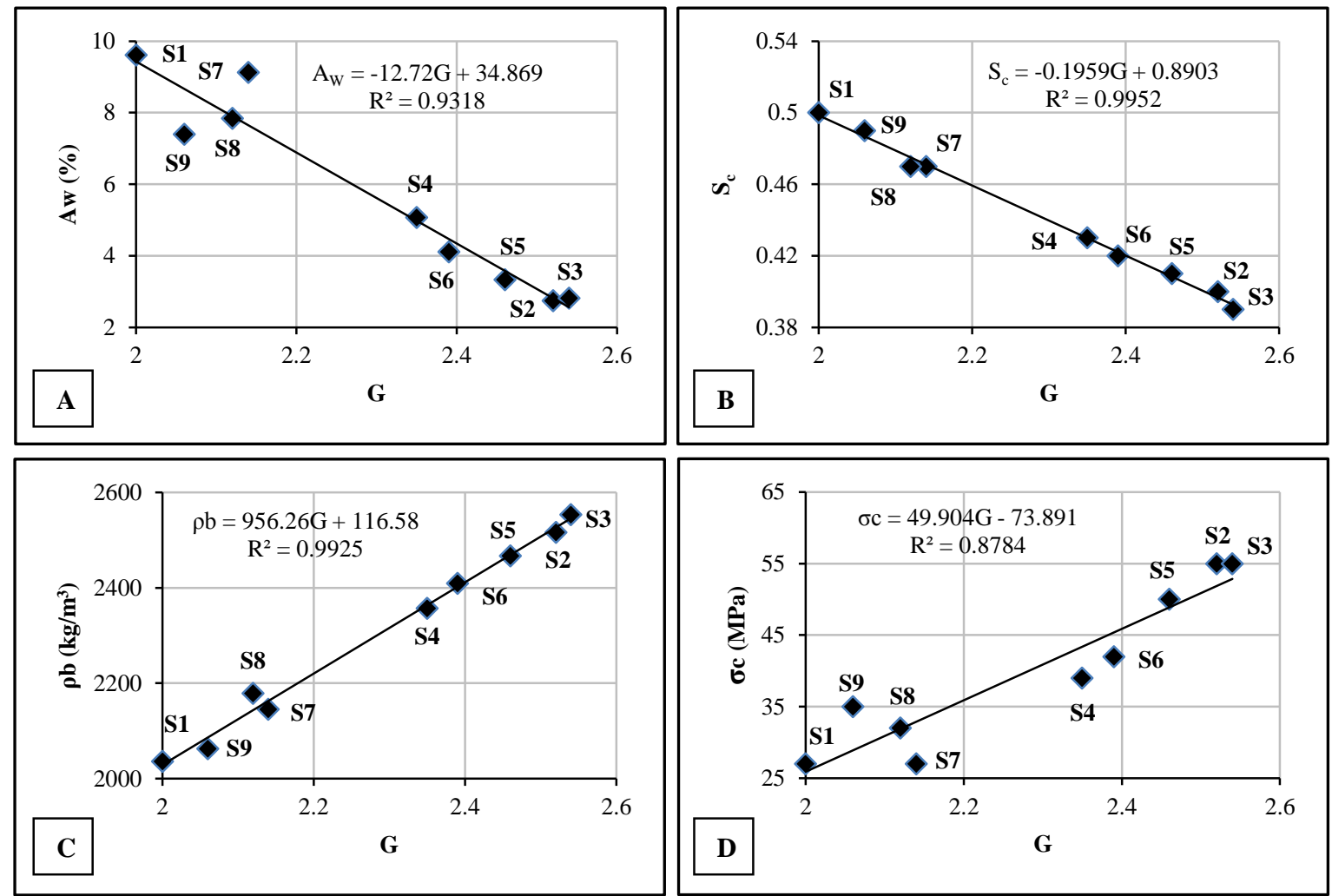

Figure 8. The apparent specific gravity versus A) water absorption, B) saturation coefficient, C) bulk density, D) uniaxial compressive strength. 

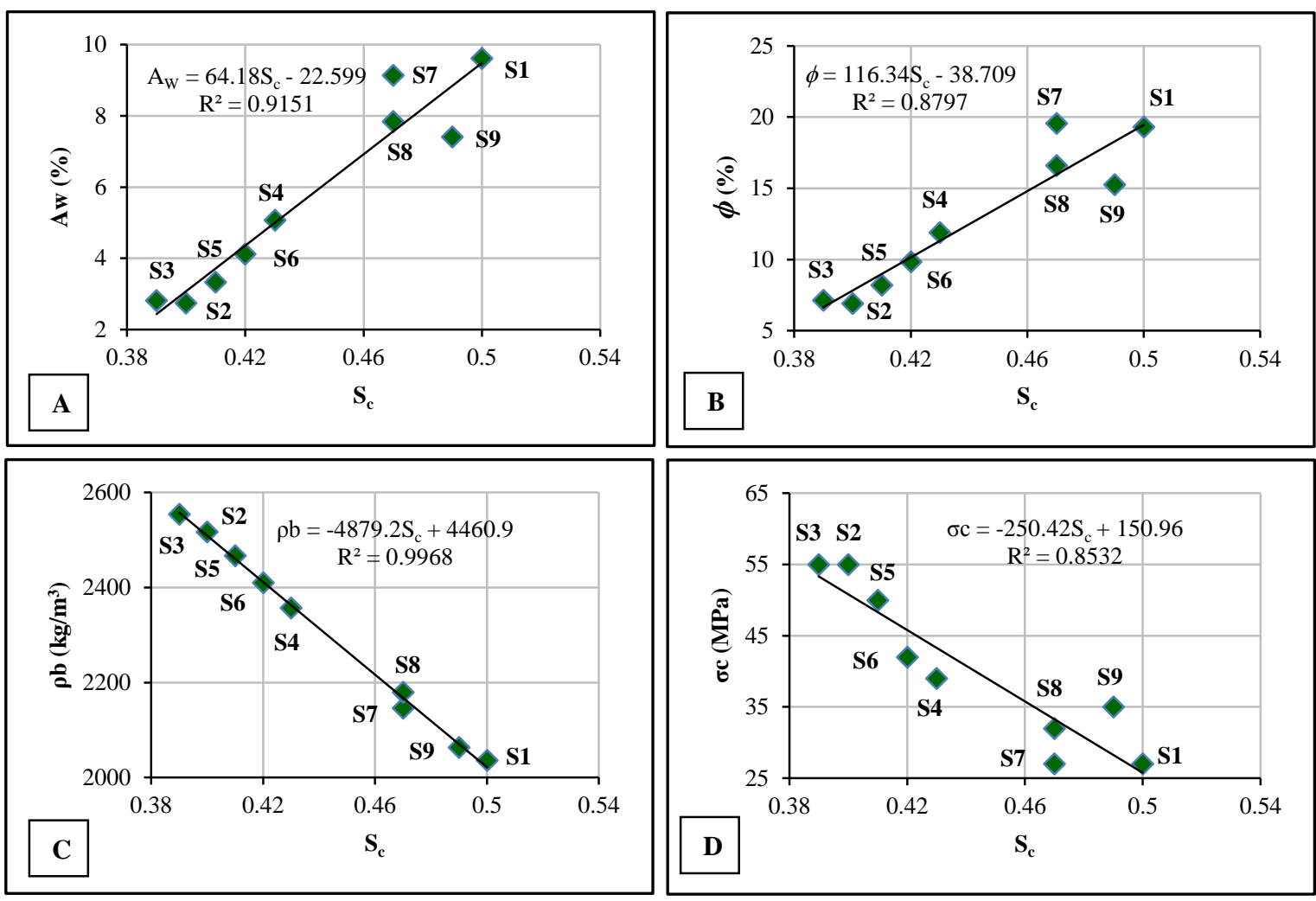

Figure 9. The saturation coefficient versus A) water absorption, B) total porosity, C) bulk density, D) uniaxial compressive strength.
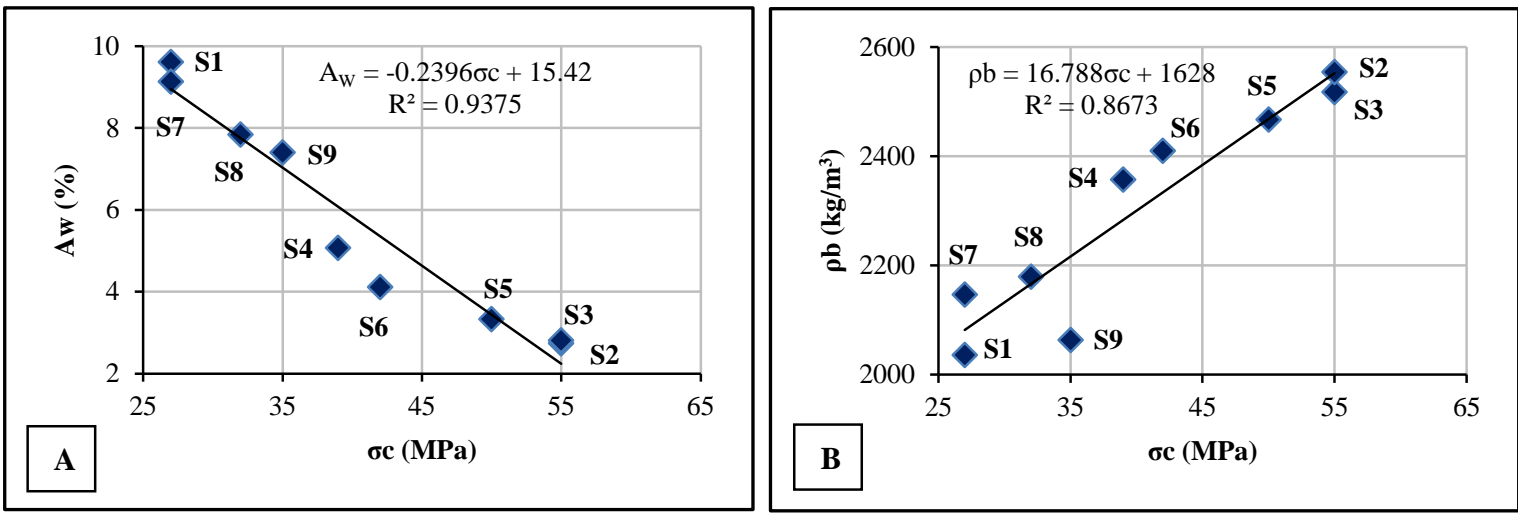

Figure 10. The uniaxial compressive strength versus A) water absorption, B) bulk density.

The samples were assessed for their suitability for building stones by comparing their measured properties with the Iraqi Standard No.1387, 1989 and ASTM C568-03-2006, which classify them into three categories: i - low density (acceptable); ii - moderate density (recommended) and iii - high density (highly recommended) (Table 4):

Table 4. Classification of the samples according to the Iraqi Standard No.1387, 1989 and ASTM C568-03-2006.

\begin{tabular}{|c|c|c|}
\hline IQ No.1387, 1989 & ASTM C568-03-2006 & Sample No. \\
\hline Low density & Acceptable & S1, S7, S8, S9 \\
\hline Moderate density & Recommended & S4, S5, S6 \\
\hline High density & Highly recommended & S2, S3 \\
\hline
\end{tabular}

The samples are classified as (moderately strong) by their uniaxial compressive strength according to (Anon, 1977) and (Geological Society Engineering Group Working Party 1977) except for (S2 and S3) which are (strong) (Table 5).

Table 5. Categorization of rocks by uniaxial compressive strength (MPa) (from Anon, 1977 and Geological Society Engineering Group Working Party 1977).

\begin{tabular}{|c|c|c|c|}
\hline Category & $\begin{array}{c}\text { Anon, } \\
\mathbf{1 9 7 7}\end{array}$ & Description & $\begin{array}{c}\text { Geological } \\
\text { Society 1977 }\end{array}$ \\
\hline $\begin{array}{c}\text { Extremely } \\
\text { weak }\end{array}$ & $<1.25$ & Extremely weak & $<1.25$ \\
\hline Weak & $1.25-5.0$ & Weak & $1.25-5.0$ \\
\hline $\begin{array}{c}\text { Moderately } \\
\text { weak }\end{array}$ & $5.0-12.5$ & Moderately weak & $5.0-12.5$ \\
\hline $\begin{array}{c}\text { Moderately } \\
\text { strong }\end{array}$ & $12.5-50$ & Moderately strong & $12.5-50$ \\
\hline Strong & $50-100$ & Strong & $50-100$ \\
\hline \multirow{2}{*}{$\begin{array}{c}\text { Extremely } \\
\text { strong }\end{array}$} & $>100$ & Very strong & $100-200$ \\
\cline { 2 - 4 } & \multicolumn{2}{|c|}{ Extremely strong } & $>200$ \\
\hline
\end{tabular}


All samples are classified as (moderately strong) according to (ISRM, 1981) and (Franklin and Dusseault, 1989) (Table 6), while they are classified as (high strength) according to (Broch and Franklin, 1972) (Table 7).

Table 6. Classification of uniaxial compressive strength (MPa) (from ISRM, 1981 and Franklin \& Dusseault, 1989).

\begin{tabular}{|c|c|c|c|}
\hline Description & $\begin{array}{c}\text { ISRM } \\
\mathbf{1 9 8 1}\end{array}$ & Description & $\begin{array}{c}\text { Franklin and } \\
\text { Dusseault, 1989 }\end{array}$ \\
\hline Very low & $<6$ & Extremely weak & $2>\sigma \mathrm{c}$ \\
\hline Low & $6-20$ & Weak & $6 \geq \sigma \mathrm{c} \geq 2$ \\
\hline Moderate & $20-60$ & $\begin{array}{c}\text { Moderately } \\
\text { weak }\end{array}$ & $20 \geq \sigma \mathrm{c} \geq 6$ \\
\hline High & $60-200$ & $\begin{array}{c}\text { Moderately } \\
\text { strong }\end{array}$ & $60 \geq \sigma \mathrm{c} \geq 20$ \\
\hline \multirow{2}{*}{ Very high } & $>200$ & Strong & $200 \geq \sigma \mathrm{c} \geq 60$ \\
\cline { 2 - 4 } & & Extremely strong & $\sigma \mathrm{c}>200$ \\
\hline
\end{tabular}

Table 7. Grades of uniaxial compressive strength (MPa) (after Broch and Franklin, 1972).

\begin{tabular}{|c|c|}
\hline Grade & Broch and Franklin, 1972 \\
\hline Very low & $<2.5$ \\
\hline Low & $2.5-7.0$ \\
\hline Medium & $7.0-25.0$ \\
\hline High & $25.5-70.0$ \\
\hline Very high & $70.0-225.0$ \\
\hline Extremely high & $>225.0$ \\
\hline
\end{tabular}

The examined rocks can be used as building stones in interior and exterior wall cladding and exterior fencing, as well as for decoration. Samples (S1, S7, S8 and S9) are best suited for use as decorative stones due to their low density, while they are not suitable for building sections that require high load bearing due to their low strength, or in places where they come into contact with water or soil, such as foundations, due to their high porosity and high ability to absorb water. Samples (S2 and S3) can be used in such places as well as areas with high humidity due to their high strength, low porosity and low water absorption capacity.

\subsection{Quarrying Conditions:}

The following are some of the essential geological and nongeological conditions and considerations for the proposed quarry in the studied area:

\subsubsection{Location and Accessibility:}

The proposed quarry is located near several villages where labor and tools are available. A new approach road of about $500 \mathrm{~m}$ in length will be required to connect the quarry to the Sinaye Old village road off the main road to the Sharya District.

\subsubsection{Availability:}

The proposed quarry site contains large quantities of rocks of good quality, uniform appearance, and homogeneous light colors suitable for utilize as building stones. Ample space is available for facility installation, site service and stockpiling. A source of electrical power is available for operational and administrative utilizes.

\subsubsection{Operations:}

The rocks can be quarried using the wedging method or the diamond cutting wire saw method. The presence of natural planes of weakness, such as the joints of different systems and the well bedding nature of the layers, will make the detachment of the stone blocks from their rockbeds easy, fast and economical. They are then taken out, dressed to provide them a pleasing appearance, and transformed into the desired commercial sizes and shapes. The blasting method can be used to a limited extent in times when masses of extractable sizes are difficult to obtain.

\subsubsection{Quarry Design:}

The geometry of the benched slope of the quarry face must take into account the high dip amount of the beds, therefore, special treatment during quarrying must be carried out by a well-experienced geologist or quarry engineer to ensure the slopes remain stable and operate in a safe system for people and equipment over the long term.

\subsubsection{Topography:}

The topography of the area plays a vital role in the extraction of rocks and the tracking of layer extensions, which greatly affects the costs of quarrying operations. The layers are well exposed in the transverse valleys that cut across the ridge. The flatirons facilitate the extraction of rocks. The low thickness of the topsoil and the absence of overburden at the studied site are encouraging factors in the exploitation of rocks and reduce the costs of extraction.

\subsubsection{Water Supply:}

Availability of water resources is a very prerequisite for quarrying operations. The studied area does not have any source of surface water such as rivers or streams. However, groundwater of permissible quality can be found at a depth of $40-50 \mathrm{~m}$ in carbonate aquifers along the extension of the Pila Spi Formation below the ground surface (Al-Jiburi and Al-Basrawi, 2013). The water will not be utilized to process the stones in the quarrying area, therefore, no effluent will be generated.

\subsubsection{Unwanted Materials:}

The chert nodules in some layers can be removed during rock cutting and processing. Innerburden or unusable varieties of rocks should be piled outside the boundaries of the quarry for utilize in the rehabilitation of the quarry and not thrown into the valleys which are the natural drainage patterns of the quarry.

\section{CONCLUSIONS}

1. The Pila Spi Formation in the Duhok anticline consists, from top to downward, of a sequence of consolidated, crystallized limestone, well-bedded to massive white or gray dolomitic limestone that is occasionally chalky and cavernous with scattered nodules of chert of different sizes and shapes in some intervals.

2. The examined rocks showed a remarkable variation in the values of their physico-mechanical properties, which showed very high significant relationships with each other.

3. Samples are classified as frost-resistant.

4. According to the Iraqi and American Standards, four samples were (low density/acceptable), three samples (moderate density/recommended) and two samples (high density/highly recommended). According to some classifications, the samples were (moderately strong) except for two of them (strong), while all of them were (moderately strong) and (high strength rocks) in other classifications.

5. The examined rocks are suitable for use as building stones in interior and exterior wall cladding and exterior fencing, as well as for decoration. Four samples are not suitable for building sections that require high load bearing or in places where they come into contact with water or soil, such as foundations, while only two samples are suitable.

6 . The quality and quantity of the rocks and quarrying conditions encourage their exploitation for building stones, with the necessity of proper planning of the proposed quarry and special treatment during quarrying. 


\section{REFERENCES}

Abd El-Hamid, M.A., Draz, W.M., Ismael, A.F., Gouda, M.A. and Sleem, S.M. (2015): Effect of Petrographical Characteristics on the Engineering Properties of Some Egyptian Ornamental Stones. International Journal of Scientific and Engineering Research, Volume 6, Issue 7, pp.116 - 123

Al-Banna, A.Sh., Ali, Dh.Kh. and Abdullah, H.H. (2013): Characteristics of Some Geotechnical Properties of Pilaspi and Injana Sedimentary Formations, at Shaqlawa Area, North Iraq. International Journal of Civil Engineering and Technology. Vol.4, Issue 6, pp. $252-260$.

Ali, M.H.; Hijab, B.R. and Al-Jassar, S.H. (1991): Engineering Geology. Dar Al-Kutub for Printing and Publishing, University of Mosul, 572 p. (in Arabic).

Al-Jiburi, H. and Al-Basrawi, N. (2013): Hydrogeological Map of Iraq, Scale 1:1000000. $2^{\text {nd }}$ ed. Baghdad, Iraq: Iraq Geological Survey Publications.

Alkadum, N.A.A. (2009): Structure of Dohuk Anticline-Northern Iraq its Tectonic Implications. Unpublished M.Sc. Thesis, University of Basrah, $140 \mathrm{p}$

Al-Saraj Bashi, M.S. (2017): Mathematical Interpolations for the Geometry and Structure of Dohuk Syncline and its Hydrogeological Investment, Northern Iraq. Unpublished M.Sc. Thesis, University of Mosul, $100 \mathrm{p}$.

American Society for Testing and Materials, ASTM C170-90 (1999): Standard Test Method for Compressive Strength of Dimension Stone. Annual Book of ASTM Standards. Vol. 04.07.3 p.

American Society for Testing and Materials, ASTM C568-03 (2006): Standard Specification for Limestone Dimension Stone. Annual Book of ASTM Standards. Vol.04.07. $2 \mathrm{p}$

American Society for Testing and Materials, ASTM C97-09 (2010): Standard Test Method for Absorption and Bulk Specific Gravity of Dimension Stone. 3 p.

Anon. (1977): The Description of Rock Masses for Engineering Purposes. Working Part Report of the Engineering Group of the Geological Society of London. Quarterly Journal of Engineering Geology, Vol. 10, pp. $355-388$

Barbaro, C.C. and Moscone, D. (2020): Going to the Source: New Perspectives in the Study of the Canaanean Blade Technology from Iraqi Kurdistan. In: Manclossi F.; Marchand, F.; Boutoille L., and Cousseran-Néré S. eds., Stone in Metal Ages. Archaeopress, Oxford, pp.52 - 63.

Bhattarai, S. and Tamrakar, N.K. (2017): Physical Properties, Strength and Durability of Selected Rocks from the Central Nepal Lesser Himalaya, Malekhu River Area for Building Stones. American Scientific Research Journal for Engineering, Technology, and Sciences, Vol.35, No.1, pp.236 - 250.

British Geological Survey (2005): Building and Roofing Stone. Mineral Profile, Natural Environment Research Council, 24 p.

Broch, E. and Franklin, J.A. (1972): Point-load strength Test. Int. J. Rock Mech. Min. Sci. 9 (6), 669-697.

Dhaher, K. A. (2009): Study of Physical and Geotechnical Properties of Some Rock Units of Pilaspi, Fatha and Injana Formations in Shaqlawa Area, Northern Iraq. Unpublished M.Sc. Thesis, College of Science, University of Baghdad, Iraq.

Fouad, S.F. (2015): Tectonic Map of Iraq, scale 1:1000000 m $3^{\text {rd }}$ edition, Iraq Geological Survey Publications, Baghdad, Iraq.

Franklin, J.A. and Dusseault, M.B. (1989): Rock Engineering. McGrawHill, New York, 600 p.

Geological Society Engineering Group Working Party (1977): The Description of Rock Masses for Engineering Purposes. Report. Q J Eng Geol 10:43-52.

Griffin, J.A. (2008): Development of a Rating Classification for Rock to be Used as Toe-Bench Material. Unpublished M.Sc. Thesis, Kent State University, 131p.

Honeyborne, D.B. (1982): The Building Limestones of France (Building Research Establishment Report). H.M.S.O., 116 p.

Iraqi Standard Specification No.2715-1987: Test Method for Compressive Strength of Natural Stone. Central Agency for Standardization and Quality Control, Ministry of Planning, Baghdad. (in Arabic).
Iraqi Standard Specification No.1387-1989: Natural Building Stone. Central Agency for Standardization and Quality Control, Ministry of Planning, Baghdad. (in Arabic).

ISRM - International Society for Rock Mechanic - Commission on the Classification of Rocks and Rock Masses (1981): Basic Geotechnical Description of Rock Masses. Int. J. Rock Mech. Min Sci. Geomech. Abstr., 18:85-110.

Jassim, S.Z. and Goff, J.C. (2006): Geology of Iraq. Published by Dolin, Prague and Moravian Museum, Brno, Czech Republic, 341 p.

Karim, K.H. and Hama, B.A. (2019): Chronicle of the Oligocene Succession (Kirkuk Group) in Duhok Governorate, Kurdistan Region, North Iraq. Journal of Zankoy Sulaimani, Vol.21, No.1, pp.75 - 90 .

Khattab, S.I. and Othman, H.M.S. (2012): Durability and Strength of Limestone Used in Building. Al-Rafidain Engineering Journal, Vol.21, No.3, pp.1 - 14.

McMillan, A.A., Gillanders, R.J. and Fairhurst, J.A. (1999): Building Stones of Edinburgh. $2^{\text {nd }}$ edn, Edinburgh Geological Society, Edinburgh.

Mirza, T.A. and Rashid, S.Gh. (2019): Evaluation of the Pila Spi Formation Carbonate Rocks for Dimension Stone, Qara Dagh Area, Kurdistan Region, NE Iraq. Iraqi Bulletin of Geology and Mining, Vol.15, No.2, pp.107 - 120 .

Moscone, D., Eramo, G., Caggiani, M.C., Morandi Bonacossi, D. and Conati Barbaro, C. (2020): Compositional Features of Cherts from the Jebel Zawa Mines (Dohuk, Kurdistan Region of Iraq) and Implications for Exploitation Strategies during the Late Chalcolithic/Early Bronze Age. Journal of Archaeological Science: Report 29 (2020), 18 p.

Omar, H.M. and Ismail, N.R. (2015): The Suitability of Limestone from Pilaspi Formation (Middle - Late Eocene) for Building Stone in Koya Area, NE Iraq. ARO, the Scientific Journal of Koya University, Vol.3, No.2, pp.18-23.

Quick, G.W. (2002): Selective Guide to the Specification of Dimension Stone. CSIRO Building, Construction and Engineering, Highett, Victoria, Australia, 9 p.

Saffet, Y. (2010): Geomechanical Properties of Construction Stones Quarried in Southwestern Turkey. Scientific Research and Essays. Vol.5, No.8, pp.750 - 757.

Saleh, Dh.Gh. (2012): The Suitability of Limestone of Fat'ha Formation for Building and Road Aggregates in Nineveh Governorate/North Iraq. Journal of Al-Anbar University for Pure Sciences, Vol.6, No.3, pp.1 - 13.

Sandrolini F. and Franzoni E. (2006): An Operative Protocol for Reliable Measurements of Moisture in Porous Materials of Ancient Buildings. Build Environ; 41:1372-80.

Sharma, P.K., Khandelwal, M. and Singh, T.N. (2006): Effect of Acidic Water on Physio-Mechanical Properties of Building Stone - A Case Study. IAEG 2006 paper number 51, pp.1 - 7 .

Sissakian, V.K., Hagopian, D.H. and Hasan, E.A. (1995): Geological Map of Al-Mosul Quadrangle - Sheet NJ - 38 - 13, scale 1:250.000, Iraq Geological Survey Publications, Baghdad, Iraq.

Spry, A.H. (1989): Stone Testing: General; In Perry, J.; Spry, A. H. and West, D. (eds), Stone in Modern Building: State of the Art. Seminar Notes, Sydney, 23 - 24 October, 1989, pp.45 - 57.

Taylor, J. and Harold, A. (1991): A. "Annual Report of Dimensional Stones”. U.S Department of Interior, Bureau of Mines, $18 \mathrm{p}$.

Zeb, A. (2009): Prediction of Effective Thermal Conductivity of Fluid Saturated Porous Media: in situ Thermo Physical Measurements. Ph.D. Thesis, Quaid-i-Azam University, Pakistan, $139 \mathrm{p}$.

Google Earth Pro V.9.145.0.2. (August 08, 2020). Sharya District, Duhok, Iraq. $36^{\circ} 48^{\prime} 40^{\prime \prime} \mathrm{N}, 43^{\circ} 01^{\prime} 27^{\prime \prime} \mathrm{E}$, elev $1981 \mathrm{ft}$. eye alt $7513 \mathrm{ft}$. [Accessed October 8, 2021]. 